\title{
Transmission of Information of the Indonesian Dual Listed Shares
}

\author{
Randi Anto ${ }^{1} \&$ Irene Rini Demi Pangestuti ${ }^{2}$ \\ ${ }^{1}$ Doctoral Program in Economics, Universitas Diponegoro, Semarang, Indonesia \\ ${ }^{2}$ Faculty Economics and Business, Universitas Diponegoro, Semarang, Indonesia \\ Correspondence: Randi Anto, Doctoral Program in Economics, Universitas Diponegoro, Semarang, Indonesia. Tel: \\ 62-8121-087-195.
}

Received: October 21, 2019

Accepted: November 18, 2019

Online Published: March 17, 2020

doi:10.5430/ijfr.v11n2p255

URL: https://doi.org/10.5430/ijfr.v11n2p255

\begin{abstract}
Various studies have been carried out in relation to the behavior of dual listing stock prices, unfortunately, study on the effects of changes in dual listing stock prices on the Indonesia Stock Exchange (IDX) is still limited. Differences in trading time and stock exchange class between one stock exchange with another in different countries raise an opportunity for the accumulation of information when one of the exchanges is experiencing a closing trading period. Indonesian companies such as PT. Telekomunikasi Indonesia (Persero) Tbk. (TLKM) whose shares are listed on the New York Stock Exchange (NYSE) and IDX experience the difference in time of their transaction which can affect the shares on the NYSE and on the IDX. This study conducted by using daily data from January 2018 to December 2018. This study found that there is a significant effect of changes in TLKM stock prices on the NYSE in (t-1) period to changes in TLKM stock prices on IDX in t-period. This finding proves that there was the existence of transmission of information between the stock exchanges utilized by investors.
\end{abstract}

Keywords: dual listing, Indonesia Stock Exchange, New York Stock Exchange, information transmission

\section{Introduction}

Globalization in capital market and reduction of economic constraints between countries makes the capital markets in the world is increasingly in a tight competition. Stock exchanges, in particular, will compete closely to find companies that will list their shares on the trading board. The current trend is that companies try to register their shares on more than one stock exchange (Sarkissian \& Schill, 2016).

The process of listing shares outside the home country of a company is very interesting as many companies from developing countries are interested in listing their shares in developed countries (Duppati, Hou, Scrimgeour, \& Hadsell, 2017; Li, Brockman, \& Zurbruegg, 2015; Sarkissian \& Schill, 2016). The shares listed by foreign companies on stock exchanges in developed countries, for example in United States, are called American Depositary Receipt (ADR) and the shares listed by foreign companies on stock exchanges on international markets are called Global Depositary Receipt (GDR) (Choi \& Kim, 2000). Therefore, investors can buy the company shares in the local market or the United States or global markets.

Generally, researches on dual listing or cross listing shares show that a company registers its shares on the international stock market to raise more funds from the international environment (Brockman \& Chung, 1999; Li et al., 2015; Park $\& \mathrm{Na}, 2017)$. Kot and Tam (2016) stated that the consideration of companies to register on the international stock market is generally based on the large amount of funds to be collected. If the amount of funds needed can be obtained on the domestic stock exchange, then the initial offering of shares (IPO) is done within its their home country, and if the amount exceeds the existing capacity, then the foreign exchange becomes an option (Hargis, 2000; Tong \& Junarsin, 2013). However, aside from the reasons on why a company is listing its shares on an international stock market, other factors from the investor's side such as the effect that may be caused by the listing of shares on more than one stock exchange or dual listing shares need to be investigated. At the present, there are a number of Indonesian companies listed on the Indonesia Stock Exchange (IDX) and abroad, such as PT. Telekomunikasi Indonesia (Persero) Tbk. (Telkom) on the New York Stock Exchange (NYSE) and PT. Aneka Tambang (Persero) Tbk. (Antam) on the Australia Stock Exchange (ASX).

In a country where there is no limit on the amount of capital flows, the investors can benefit by arbitrating shares through speculation on differences in price fractions that exist on different stock exchanges. For example, someone can 
buy shares in the local market then convert them to ADR and then sell them to foreign markets, and vice versa (Fernandes \& Ferreira, 2008). Various studies have been carried out in relation to the behavior of dual listing stock prices, including a research by Kot and Tam (2016) concerning the transfer of share price information recorded in China. A research by Duppati et al. (2017) studied shares listed in Shanghai Stock Exchange and New York Stock Exchange; and Chan, Chockalingam, and Lai (2000) studied shares listed on the Pacific region stock exchanges with the New York Stock Exchange.

Unfortunately, researches on the effects of changes in dual listing stock prices on IDX is still limited. Differences in trading time and stock exchange class between one stock exchange with another in different countries raise an opportunity for the accumulation of information when one of the exchanges is experiencing a closing trading period. This may cause different information to occur when one of the markets is opened to make a transaction again. For this reason, this study examines information transmission in the form of changes in dual listing stock prices on IDX and other stock exchanges. This research contributes to the development of literature on dual-listing Indonesian company shares and the process of transmitting information from IDX to other stock exchanges which is NYSE, and vice versa. This research also has implications for policy makers.

The rest of the research is written as follows: section 2 provides literature review and hypotheses development, section 3 presents methodology, section 4 provides empirical results, and section 5 explains the conclusion of the research.

Robiyanto (2018b) stated that capital markets are considered internationally integrated if assets with the same (identical) risk will have the same price although they are traded on different capital markets. Lately, there have been indications of an acceleration of the process of integration among the capital markets in the world. This is possible because of the gradual exemption of restrictions on share ownership by foreign parties imposed by a government in some capital markets (Robiyanto, 2018a). Rapid developments in information and communication technology, such as the internet, online trading and increasingly sophisticated information providers in the form of international exchange data such as Bloomberg and Reuter Datalinks also support this process.

Meanwhile, the dependence between capital markets in the world has been studied by Muharam, Anwar, and Robiyanto (2019); Muharam, Mawardi, Arfinto, and Najmudin (2019); Mulyadi (2012); Oprea and Stoica (2018); Suganda and Hariyono (2018); Wahyudi, Najmudin, Laksana, and Rachmawati (2018). The empirical results reveal that most capital markets in the world are generally efficient where this can be seen in the rapid response to new information created by other capital markets. In addition, it was also found that the capital market with the same behavior is the capital market geographically close and economically related, and has similar variety of shares traded (example: dual listing). The more open and more advanced the international capital market, the more the companies are able to obtain capital for their business activities. If efforts to obtain funds cannot be met by the domestic market, then the company can do a dual listing.

Indonesian companies such as Telkom whose shares are listed on the NYSE and IDX experience the difference in time of their transaction which can affect the shares on the NYSE and on the IDX (as stated by Hargis (2000)). Moreover, considering the fact that there is a difference in trading time where for (t-1) period on the NYSE starts at 9.30 a.m. ET (9.30 p.m. WIB) until 4.00 p.m. ET (4.00 a.m. WIB) with (t) on IDX starting at 9:00 a.m. WIB until 3.50 p.m. WIB. Therefore, this raises the potential for the influence of changes in Telkom stock prices on the NYSE in (t-1) period with changes in Telkom shares in t-period on IDX.

For this reason, hypotheses that can be proposed are as follows:

H1: There is a significant influence of changes in Telkom stock prices on the NYSE in (t-1) period to changes in Telkom stock prices on IDX in t-period.

$\mathrm{H} 2$ : There is a significant influence of changes in Telkom stock prices in ( $\mathrm{t}-1)$ period on IDX to changes in Telkom stock prices on the NYSE in t-period.

\section{Method}

\subsection{Data}

The data needed in this study were: (1) daily closing stock price of PT. Telekomunikasi Indonesia (Persero) Tbk. on the Indonesia Stock Exchange during the study period (January 2018 to December 2018); and (2) daily closing share price of PT. Telekomunikasi Indonesia (Persero) Tbk. on the New York Stock Exchange during the study period (January 2018 to December 2018). All data was obtained from Bloomberg. 


\subsection{Variables}

Below are operational definitions of the variables and their measurements:

TLKM return on IDX ( $\triangle$ TLKM IDX) was measured by the following formula:

$$
\Delta \text { TLKM IDX }_{\mathrm{t}}=\frac{\text { TLKM IDX }_{\mathrm{t}}-\text { TLKM IDX }_{\mathrm{t}-1}}{\operatorname{TLKM~IDX}_{\mathrm{t}-1}}
$$

Where:

TLKM IDX $\mathrm{X}_{\mathrm{t}}$ : TLKM share price on IDX in t-period

TLKM IDX $_{\mathrm{t}-1}$ : TLKM share price on IDX in (t-1) period

TLKM return on NYSE (LTLKM NYSE) was measured by the following formula:

$$
\Delta \text { TLKM NYSE }_{\mathrm{t}}=\frac{\text { TLKM NYSE }_{\mathrm{t}}-\mathrm{TLKM} \mathrm{NYSE}_{\mathrm{t}-1}}{\text { TLKM NYSE }_{\mathrm{t}-1}}
$$

Where:

TLKM NYSE: : TLKM share price on NYSE in t-period

TLKM NYSE $_{\mathrm{t}-1}$ : TLKM share price on NYSE in $(\mathrm{t}-1)$ period

\subsection{Models}

The regression analysis equation model used to analyze the effect of changes in Telkom stock price on the NYSE in $(\mathrm{t}-1)$ period on changes in Telkom stock price on IDX in t-period is as follows:

$$
\Delta \text { TLKM IDX }_{\mathrm{t}}=\alpha+\beta 1 \Delta \text { TLKM NYSE }_{\mathrm{t}-1}+\varepsilon
$$

Where:

$\triangle$ TLKM IDX $_{\mathrm{t}}$ : Return of Telkom on the IDX on $\mathrm{t}$

$\triangle$ TLKM NYSE $_{\mathrm{t}-1}$ : Return of Telkom on the NYSE on t-1

$\alpha$ : Constant

$\beta 1$ : Regression coefficient

$\varepsilon$ : Residual error

The regression analysis equation model used to analyze the effect of changes in Telkom stock price on IDX in t-period on changes in Telkom stock price on NYSE in t-period is as follows:

$$
\Delta \text { TLKM NYSE }_{\mathrm{t}}=\alpha+\beta 1 \Delta \mathrm{TLKM} \mathrm{IDX}_{\mathrm{t}}+\varepsilon
$$

Where:

$\triangle \mathrm{TLKM} \mathrm{IDX}_{\mathrm{t}}$ : Return of Telkom on the IDX on $\mathrm{t}$

$\triangle$ TLKM NYSE $_{\mathrm{t}}$ : Return of Telkom on the NYSE on $\mathrm{t}$

$\alpha$ : Constant

$\beta 1$ : Regression coefficient

$\varepsilon$ : Residual error

\section{Results and Discussions}

In accordance with the guidance in conducting regression analysis, as stated by Gujarati and Porter (2009), a regression equation must have data that are normally distributed, free of heteroscedasticity, and free of autocorrelation to obtain a good and unbiased regression equation. Based on the results of the normality test data, it was found that the data used in this regression equation were normally distributed, there was no autocorrelation and heteroscedasticity free. Therefore, it met the requirements to do a good regression analysis.

In this study there were two regression equations:

1. Regression equation that analyzed the effect of TLKM stock returns on NYSE in (t-1) period on TLKM stock returns on IDX in t-period. 
2. Regression equation that analyzed the effect of TLKM stock returns on IDX in t-period on TLKM stock returns on NYSE in t-period.

In the following section, each of the regression equations will be elaborated.

\subsection{Analysis of the Effect of TLKM Stock Return on NYSE in (t-1) Period on TLKM Stock Return on IDX in t-Period}

It was found that TLKM stock return on NYSE in (t-1) period has a significant positive effect on TLKM stock return on IDX in t-period. Table 1 presents the regression result. Based on Table 1, it can be seen that the TLKM NYSE $\mathrm{t}_{\mathrm{t}}$ regression coefficient has a positive direction of 0.129 . This shows that TLKM stock return on NYSE in (t-1) period had a positive influence on TLKM return on IDX in t-period. The t-value of the $\triangle$ TLKM NYSE t-1 $_{\text {regression }}$ coefficient is 1.866 and greater than the t-table value with 225 degrees of freedom at a $10 \%$ significance level of 1.645. The value of $\mathrm{t}$-value is greater than $\mathrm{t}$-table. It means that $\mathrm{H} 1$ which states that there is a significant influence of changes in TLKM stock price in (t-1) period on the NYSE to changes in TLKM stock price in t-period on IDX, is accepted.

Table 1. Results of regression analysis of $\Delta \mathrm{TLKM} \mathrm{NYSE}_{\mathrm{t}-1} \rightarrow \Delta \mathrm{TLKM} \mathrm{IDX}_{\mathrm{t}}$

\begin{tabular}{llll}
\hline Variable & Regression Coefficient & t-Value & F-Value \\
\hline Constant & 0.0003012 & 0.069 & $3.582^{*}$ \\
$\Delta$ TLKM NYSE $_{\mathrm{t}-1}$ & 0.129 & $1.866^{*}$ & \\
\hline $\mathrm{R}^{2}: 0.016$ & & & \\
\hline
\end{tabular}

Notes: *significant at $10 \%$

Source: Bloomberg, processed.

The $\triangle$ TLKM NYSE $\mathrm{t}_{\mathrm{t}-1}$ regression coefficient value of 0.129 means that if TLKM stock return on NYSE in (t-1) period increased by $1 \%$, it would increase the TLKM stock return on IDX in t-period by $0.129 \%$. This happened because the domestic stock market would respond to changes in price on international exchanges where domestic stock market registered their shares due to time differences which were often referred to as overnight information. These findings are consistent with previous studies on dual listings such as a research by Dodd (2011); Hegde, Lin, and Varshney (2016); Kot and Tam (2016) who found that changes in the price of dual listing shares in the United States had a very dominant influence on changes in the price of dual listing shares in the home country stock exchange.

This regression equation had a calculated F-value of 3.582 which is greater than the F-table at degrees of freedom (1: 224 ) at a $10 \%$ significance level of 2.726 . Therefore, it can be concluded that this regression equation was significant and feasible to use. Furthermore, this regression equation has a coefficient of determination of $1.6 \%$ which means that the independent variables used in this regression equation were able to explain $1.6 \%$ of the variation in the dependent variable in this regression equation and the rest was explained by other variables not used in this regression equation.

\subsection{Analysis of the Effect of TLKM Stock Return on IDX in t-Period on TLKM Stock Return on NYSE in t-Period}

It was found that TLKM stock return on IDX in t-period has a significant positive effect on TLKM stock return on NYSE in t-period. Table 2 presents the regression result.

Table 2. Results of regression analysis of $\Delta \mathrm{TLKM} \mathrm{IDX}_{\mathrm{t}} \rightarrow \Delta \mathrm{TLKM} \mathrm{NYSE}_{\mathrm{t}}$

\begin{tabular}{llll}
\hline Variable & Regression Coefficient & t-Value & F-Value \\
\hline Constant & 0.001899 & 0.811 & $55.688^{*}$ \\
$\Delta$ TLKM IDX $_{\mathrm{t}}$ & 0.492 & $7.997^{*}$ & \\
\hline $\mathrm{R}^{2}: 0.19$ & & & \\
\hline
\end{tabular}

Notes: *significant at $1 \%$

Source: Bloomberg, processed. 
Based on Table 2, it can be seen that the $\triangle \mathrm{TLKM}$ IDX $_{\mathrm{t}}$ regression coefficient has a positive direction of 0.492 . This shows that the TLKM stock return on IDX in t-period (intraday return) had a positive influence on the TLKM stock return on IDX in t-period. The $\mathrm{t}$-value of the $\triangle \mathrm{TLKM}$ IDX $\mathrm{t}$ regression coefficient is 7.997 and greater than the $\mathrm{t}$-table value with 225 degrees of freedom at a $1 \%$ significance level of 2.576 . The value of $t$-value is greater than $\mathrm{t}$-table. It means that $\mathrm{H} 2$ which states that there is a significant influence of changes in TLKM stock price in t-period on the IDX to changes in TLKM stock price in t-period on NYSE, is accepted.

The $\triangle T L K M ~ I D X_{t}$ regression coefficient value of 0.492 means that if TLKM stock return in IDX in t-period increased by $1 \%$, it would increase TLKM stock return on the NYSE in t-period by $0.492 \%$. These findings are consistent with the findings by Chowdhry and Nanda (1991) which show that changes in share prices on the domestic stock exchange had a strong influence on stock prices on foreign exchanges. It was because the shares of a company listed on a foreign exchange were more likely to follow the condition of the country where the company was located and operating, including matters affecting the issuer's shares. Furthermore, these findings also show that the effect of stock return on domestic exchanges was greater than the influence of foreign exchange market return. These findings also support the conclusions of a study conducted by Chan, Hameed, and Kang (2013); Li et al. (2015) that shares which recorded abroad were more influenced by domestic factors than the home country, because the company's operational activities were more affected by the conditions in which the issuer company was located.

This regression equation had a calculated F-value of 55.688 which is greater than the F-table at degrees of freedom (1: 224) at a $1 \%$ significance level of 6.63 . Therefore, it can be concluded that this regression equation was significant and feasible to use. Furthermore, this regression equation has a coefficient of determination of $19 \%$ which means that the independent variables used in this regression equation were able to explain $19 \%$ of the variation in the dependent variable in this regression equation and the rest was explained by other variables not used in this regression equation.

Liu and Bogomolov (2013) argued that shares listed on more than one stock exchange would tend to move in the same range and were coordinated with the price of shares whose shares were on other exchanges. It was referred to as information transfer (Beirne, Caporale, Schulze-Ghattas, \& Spagnolo, 2008; Wang, Gunasekarage, \& Power, 2005). In this study, empirical evidence is obtained that the stock studied (TLKM shares listed on the IDX and the NYSE) had coordinated stock movements. This could be seen from the overnight return of the TLKM shares on the NYSE has a positive influence on intraday return on IDX and the intraday return of the TLKM shares on the NYSE is influenced by intraday return on IDX. This study also has an empirical evidence that changes in share prices on the domestic stock exchange had a stronger influence on changes in share prices on foreign exchanges.

\section{Conclusion}

This study found that there is a significant positive effect of changes in TLKM stock price on the NYSE in (t-1) period to changes in TLKM stock price on IDX in t-period. This shows that there was the existence of transmission of information between the stock exchanges utilized by investors. Therefore, the investors, in conducting trading activities on TLKM shares on IDX, must pay attention to the movements of the TLKM stock price on the New York Stock Exchange in (t-1) period. This is important to do because the price movements of the TLKM stock price on the New York Stock Exchange can be preliminary information at each trading session on the Indonesia Stock Exchange so as to provide an investment decision plan for the TLKM stock. They need to take buyer positions at the beginning of the trading session on IDX if a positive return is obtained from the TLKM stock on the NYSE, and sell at the end of the trading session on IDX if they want a short-term return through one-day trading activities. However, if the return of the TLKM stock on the NYSE are negative, the investors are advised not to take any position on the TLKM stock on IDX.

This study has limitations in terms of the variables examined. This study used only one variable as a means of information transfer which is stock return as a determinant of stock return both on domestic and foreign exchanges. This research has not converted stock price in the form of ADR (American Depository Receipts) with USD denomination into price per share in IDR. Future research is expected to conduct studies on other variables besides information transfer in the form of stock returns, such as the liquidity of a stock and stock order flow at the beginning of a trading session. Furthermore, it is also necessary to consider conducting a study involving the risk of the home country of the stock carrying out a dual listing including the risk of changes in foreign exchange rates.

\section{References}

Beirne, J., Caporale, G. M., Schulze-Ghattas, M., \& Spagnolo, N. (2008). Volatility Spillovers and Contagion from Mature to Emerging Stock Markets. IMF Working Paper. https://doi.org/10.2139/ssrn.1340401 
Brockman, P., \& Chung, D. Y. (1999). Cross-Listing and Firm Liquidity on the Stock Exchange of Hongkong. Managerial Finance, 25(1), 64-88. https://doi.org/10.1108/03074359910765867

Chan, K., Chockalingam, M., \& Lai, K. W. L. (2000). Overnight Information and Intraday Trading Behavior: Evidence from NYSE Cross-Listed Stocks and Their Local Market Information. Journal of Multinational Financial Management, 10, 495-509. https://doi.org/10.1016/S1042-444X(00)00030-X

Chan, K., Hameed, A., \& Kang, W. (2013). Stock price synchronicity and liquidity. Journal of Financial Markets, 16(3), 414-438. https://doi.org/10.1016/j.finmar.2012.09.007

Choi, Y. K., \& Kim, D.-S. (2000). Determinants of American Depository Receipts and Their Underlying Stock Returns Implications for International Diversification. International Review of Financial Analysis, 9, 351-368. https://doi.org/10.1016/S1057-5219(00)00041-7

Chowdhry, B., \& Nanda, V. (1991). Multimarket Trading and Market Liquidity. Review of Financial Studies, 4(3), 483-511. https://doi.org/10.1093/rfs/4.3.483

Dodd, O. (2011). Price, Liquidity, Volatility, and Volume of Cross-listed Stocks. Doctor of Philosophy in Finance Ph.D. Thesis, Durham University. Retrieved from http://etheses.dur.ac.uk/867/

Duppati, G., Hou, Y., Scrimgeour, F., \& Hadsell, L. (2017). The dynamics of price discovery for cross-listed stocks evidence from US and Chinese markets. Cogent Economics \& Finance, 5(1). https://doi.org/10.1080/23322039.2017.1389675

Fernandes, N., \& Ferreira, M. A. (2008). Does international cross-listing improve the information environment. Journal of Financial Economics, 88(2), 216-244. https://doi.org/10.1016/j.jfineco.2007.06.002

Gujarati, D. N., \& Porter, D. C. (2009). Essentials of Econometrics (4th ed.). McGraw-Hill Education.

Hargis, K. (2000). International Cross-Listing and Stock Market Development in Emerging Economies. International Review of Economics \& Finance, 9, 101-122. https://doi.org/10.1016/S1059-0560(99)00048-9

Hegde, S., Lin, H., \& Varshney, S. (2016). Investor recognition and liquidity: evidence from dual listing on the NYSE and NASDAQ. Applied Economics Letters, 24(4), 229-232. https://doi.org/10.1080/13504851.2016.1178841

Kot, H. W., \& Tam, L. H. K. (2016). Are stock price more informative after dual-listing in emerging markets? Evidence from Hong Kong-listed Chinese companies. Pacific-Basin Finance Journal, 36, 31-45. https://doi.org/10.1016/j.pacfin.2015.12.004

Li, S., Brockman, P., \& Zurbruegg, R. (2015). Cross-listing, firm-specific information, and corporate governance: Evidence from Chinese A-shares and H-shares. Journal of Corporate Finance, 32, 347-362. https://doi.org/10.1016/j.jcorpfin.2014.10.008

Liu, L., \& Bogomolov, T. (2013). The Law of One Price and Arbitrage on China's Dual-listings. International Journal of Banking and Finance, 9(2), 58-76.

Muharam, H., Anwar, R. J., \& Robiyanto, R. (2019). Islamic stock market and sukuk market development, economic growth, and trade openness (the case of Indonesia and Malaysia). Business: Theory and Practice, 20, 196-207. https://doi.org/10.3846/btp.2019.19

Muharam, H., Mawardi, W., Arfinto, E. D., \& Najmudin, N. (2019). Volatility spillovers under difference in the degree of market integration: Evidence from the selected Asian and Eastern European stock markets. Journal of International Studies, 12(1), 134-150. https://doi.org/10.14254/2071-8330.2019/12-1/9

Mulyadi, M. S. (2012). Analysis of Volatility Spillover in Indonesia, USA and Japan Capital Market. African Journal of Business Management, 6(27). https://doi.org/10.5897/ajbm11.2054

Oprea, O.-R., \& Stoica, O. (2018). Capital Markets Integration and Economic Growth. Montenegrin Journal of Economics, 14(3), 23-35. https://doi.org/10.14254/1800-5845/2018.14-3.2

Park, Y., \& Na, K. (2017). The Effects of Listing Status on a Firm's Lease Accounting: Evidence from South Korea. Gadjah Mada International Journal of Business, 19(1), 77-92. https://doi.org/10.22146/gamaijb.12848

Robiyanto, R. (2018a). Gold VS Bond: What Is the Safe Haven for the Indonesian and Malaysian Capital Market?. Gadjah Mada International Journal of Business, 20(3), 277-302. https://doi.org/10.22146/gamaijb.27775

Robiyanto, R. (2018b). Indonesian Stock Market’s Dynamic Integration with Asian Stock Markets and World Stock 
Markets. Jurnal Pengurusan, 52, 181-192. https://doi.org/10.17576/pengurusan-2018-52-15

Sarkissian, S., \& Schill, M. J. (2016). Cross-Listing Waves. Journal of Financial and Quantitative Analysis, 51(1), 259-306. https://doi.org/10.1017/s0022109016000016

Suganda, T. R., \& Hariyono, A. R. (2018). The Integration of ASEAN-5 Capital Market after the Donald Trump Election. Jurnal Keuangan dan Perbankan, 22(4), 656-669.:https://doi.org/10.26905/jkdp.v22i4.1990

Tong, S., \& Junarsin, E. (2013). Do Private Firms Outperform SOE Firms after Going Public in China Given their Different Governance Characteristics?. Gadjah Mada International Journal of Business, 15(2), 133-170. https://doi.org/10.22146/gamaijb.5699

Wahyudi, S., Najmudin, Laksana, R. D., \& Rachmawati, R. (2018). Assessing the contagion effect on herding behaviour under segmented and integrated stock markets circumstances in the USA, China, and ASEAN-5. Economic Annals-XXI (2018), 169(1-2), 15-20. https://doi.org/10.21003/ea.V169-03

Wang, Y., Gunasekarage, A., \& Power, D. M. (2005). Return and Volatility Spillovers from Developed to Emerging Capital Markets: the Case of South Asia. In Asia Pacific Financial Markets in Comparative Perspective: Issues and Implications for the 21st Century. Elsevier Ltd. 